\title{
Post-mortem characterization of Dorper x Santa Inês lambs fed diets containing alternative foods
}

\author{
[Caracterização do post mortem de cordeiros Dorper x Santa Inês submetidos a dietas contendo \\ alimentos alternativos]
}

\section{"Scientific Article/Artigo Científico"}

\author{
Andrezza Miguel Silva ${ }^{1 *}$, Cristiane Leal dos Santos-Cruz ${ }^{2}$, Suely dos Santos Rocha ${ }^{3}$, Márcio dos \\ Santos Pedreira ${ }^{2}$
}

\author{
${ }^{1}$ Departamento de Zootecnia, Universidade do Estado de Mato Grosso (UNEMAT), Pontes e Lacerda-MT, Brasil. \\ ${ }^{2}$ Departamento Tecnologia Rural e Animal, Universidade Estadual do Sudoeste da Bahia (UESB), Itapetinga-BA, \\ Brasil. \\ ${ }^{3}$ Universidade Estadual do Sudoeste da Bahia (UESB), Itapetinga-BA, Brasil. \\ * Corresponding author/Autora para correspondência: E-mail: andrezzamiguel@ hotmail.com
}

\begin{abstract}
The objective of this study was to evaluate the post-mortem characteristics of lambs fed diets containing alternative foods. Twenty Dorper x Santa Inês castrated male lambs were used. The experimental diets were composed of ground corn, soybean meal, mineral supplement, urea, and Tifton- 85 hay (forage). In addition to these ingredients, cottonseed, sunflower meal, and castor bean cake were used as alternative foods in the proportions of 10,8 , and $8 \%$ of $\% \mathrm{DM}$, respectively. The experimental design was completely randomized with four treatments (diets) and five replicates (lambs). The experiment lasted 106 days, with 14 days for adaptation and 92 days for evaluation and data collection. At the end of the confinement period, the lambs were slaughtered and the carcasses kept under cooling for a period of 24 hours. The $\mathrm{pH}$ and carcass temperature (internal and external) were measured in the Longissimus lumborum muscle. The temperature and relative humidity of the cold chamber were obtained. Muscle $\mathrm{pH}$ was altered as a function of diet and reached a value of 5.78 (lower $\mathrm{pH}$ ) when lambs received the diet with castor bean cake. The internal carcass temperature was higher in the lambs that received the diet containing cottonseed $\left(19.98^{\circ} \mathrm{C}\right)$, sunflower meal $\left(19.71^{\circ} \mathrm{C}\right)$, and castor bean cake $\left(19.87^{\circ} \mathrm{C}\right)$. The muscle $\mathrm{pH}$ correlated in a moderate and positive way with the temperature of the carcass (internal and external) and of the cold chamber, in the different diets evaluated. There was positive correlation with values ranging from moderate to high between humidity of the cold chamber and the temperature (internal and external of the carcass; and of the cold chamber). The alternative foods can be used as ingredients in the formulation of diets for Dorper x Santa Inês lambs, as it promoted the proper development of the post-mortem process, which is characteristic of good quality sheep meat.
\end{abstract}

Keywords: agro-industrial co-products; sheep; $\mathrm{pH}$; temperature.

\begin{abstract}
Resumo
Objetivou-se avaliar as características do post mortem de cordeiros alimentados com dietas contendo alimentos alternativos. Foram utilizados 20 cordeiros, machos castrados, mestiços Dorper x Santa Inês, com idade aproximada de 90 dias e peso médio de $20 \mathrm{~kg}$. As dietas experimentais foram compostas por milho moído, farelo de soja, suplemento mineral, ureia e feno de Tifton-85 (volumoso). Além desses ingredientes foram utilizados como alimentos alternativos o caroço de algodão, farelo de girassol e torta de mamona nas proporções de 10,8 e $8 \%$ da (\%MS), respectivamente. O delineamento experimental foi o inteiramente casualizado com quatro tratamentos (dietas) e cinco repetições (cordeiros). O experimento teve duração de 106 dias, sendo 14 dias referentes ao período de adaptação e 92 dias para avaliação e coleta de dados. Ao fim do período de confinamento os cordeiros foram abatidos, as carcaças mantidas em resfriamento por um período de 24 horas. No músculo Longissimus lumborum foram realizadas as medidas de $\mathrm{pH}$, temperatura da carcaça (interna e externa); e a temperatura e umidade relativa do ar da câmara fria foram mensuradas. $\mathrm{O}$ pH
\end{abstract}


muscular foi alterado em função da dieta e alcançou valor de 5,78 (menor $\mathrm{pH}$ ) quando os cordeiros receberam a dieta com a torta de mamona. A temperatura interna apresentou-se superior na carcaça dos cordeiros que receberam a dieta contendo caroço de algodão $\left(19,98^{\circ} \mathrm{C}\right)$, farelo de girassol $\left(19,71^{\circ} \mathrm{C}\right)$ e torta de mamona $\left(19,87^{\circ} \mathrm{C}\right)$. $\mathrm{O} \mathrm{pH}$ muscular correlacionou-se de forma moderada e positiva com a temperatura da carcaça (interna e externa) e da câmara fria, nas diferentes dietas avaliadas, bem como permitiram a existência de correlação positiva com valores de variando de moderado a alto entre a umidade da câmara fria e a temperatura (interna e externa da carcaça; e da câmara fria). Os alimentos alternativos podem ser utilizados como ingredientes na formulação de dietas para cordeiros Dorper x Santa Inês, por promoverem o desenvolvimento adequado do processo post mortem, característicos de uma carne ovina de boa qualidade.

Palavras-chave: coprodutos agroindustriais; ovinos; $\mathrm{pH}$; temperatura.

\section{Introduction}

After the animal slaughter, in the postmortem period, several changes occur within the muscle to transform it into meat. This process is divided into pre-rigor and rigor phases. Firstly, a depletion of the total available energy takes place in the muscle, followed by a shift from aerobic to anaerobic metabolism, which, in turn, leads to the production of lactic acid (Álvarez et al., 2019).

As the energy reserves decline postmortem, the muscles in the carcass enter rigor mortis and the muscle temperature drops, due to the cessation of blood supply and the application of chilling. A faster than normal decline in $\mathrm{pH}$ combined with a higher than normal pre-rigor chilling temperature can result in substantial impacts on glycolysis, post-mortem muscle proteins, and, subsequently, on meat quality attributes (Kim et al., 2014).

So, to ensure consistent production of the highest quality meat possible, those involved in the meat industry must understand these biological processes and implement optimizing management practices (Ferguson and Gerrard, 2014).

Meat is the product resulting from several biochemical and physiological changes that the muscle undergoes after the animal slaughter. The final quality is affected by innumerable intrinsic and extrinsic factors, among which feed plays a fundamental role in the accumulation of body energy reserves, with an effect on the nutritional meat quality.

The intensification of sheep production systems has positive consequences, such as reduction in slaughter age, better meat quality, and increased working capital (Scarpino et al., 2014) as well as higher cost of feeding the herd. Among the various diet components, the greater impact on the final cost of a feed is the protein source, being soybean the main grain used.
The use of co-products is a practice capable of reducing these costs since it allows replacing traditional diets. For the success of this type of management, one must investigate the efficiency of the animal in face of diets based on these ingredients (Santos et al., 2020), among which stand out the cottonseed, sunflower meal, and the castor bean cake.

The objective of this study was to evaluate the post-mortem characteristics of Dorper x Santa Inês lambs submitted to diets containing alternative foods (whole cottonseed, sunflower meal, and castor bean cake).

\section{Material and Methods}

Twenty Dorper x Santa Inês castrated lambs were used, with an approximate age of 90 days and an average weight of $20 \mathrm{~kg}$. The experimental design was completely randomized with four treatments (diets) and five replicates (lambs).

Experimental diets consisted of ground corn, soybean meal, urea, and mineral mix, distinct due to the presence of different agroindustrial co-products (cottonseed, sunflower meal, and castor bean cake) in the proportions of 10,8 , and $8 \%$ of the diet dry matter, respectively, to balance the protein and energy. Represented, therefore in the following way: Diet 1 traditional; Diet 2 - whole cottonseed (CS); Diet 3 - sunflower meal (SM) and Diet 4 - castor bean cake (CB), and as forage, the Tifton-85 hay (Cynodon spp.) was used.

The castor bean cake was detoxified using $\mathrm{Ca}(\mathrm{OH})_{2}$ solution $(1 \mathrm{~kg}$ for every 10 liters of water), in the amount of $60 \mathrm{~g}$ of $\mathrm{Ca}(\mathrm{OH})_{2}$ per $\mathrm{kg}$ of cake, at the raw material base, as recommended by Oliveira et al. (2007).

The diets were calculated considering the requirements established by the NRC (2007), aiming to an average daily gain of $200 \mathrm{~g} / \mathrm{day}$, supplied ad libitum in an amount of $4.5 \%$ of live 
weight, previously weighed in a complete mixture, in proportion 50:50 (forage: concentrate). The proportion of the ingredients and the chemical-bromatological composition of the diets are shown in Table 1.

The experiment lasted 106 days, being 14 days for the adaptation of the animals to the experimental conditions, and 92 days of evaluation and data collection. The lambs had fresh water in the stalls and were fed twice a day at 7:00 a.m. and 3:00 p.m., admitting 20\% of leftovers and the total supplied adjusted daily, depending on the amount of leftovers from the previous day.

Table 1. Proportion of the ingredients and bromatological composition of the diets.

\begin{tabular}{|c|c|c|c|c|}
\hline & \multicolumn{4}{|c|}{ Diet } \\
\hline & Traditional & Cottonseed & Sunflower meal & Castor bean cake \\
\hline \multicolumn{5}{|l|}{ Ingredients (\% DM) } \\
\hline Tifton hay & 50.0 & 50.0 & 50.0 & 50.0 \\
\hline Ground corn & 36.5 & 30.5 & 34.5 & 34.5 \\
\hline Soybean meal & 12.0 & 8.0 & 6.0 & 6.0 \\
\hline Cottonseed & - & 10.0 & - & - \\
\hline Sunflower meal & - & - & 8.0 & - \\
\hline Castor bean cake & - & - & - & 8.0 \\
\hline Urea & 1.0 & 1.0 & 1.0 & 1.0 \\
\hline Mineral supplement ${ }^{1}$ & 0.5 & 0.5 & 0.5 & 0.5 \\
\hline \multicolumn{5}{|l|}{ Bromatological composition } \\
\hline Dry matter $(\%)$ & 86.2 & 86.6 & 87.4 & 85.8 \\
\hline Organic matter $^{2}$ & 94.4 & 94.3 & 94.3 & 93.7 \\
\hline Mineral matter ${ }^{2}$ & 5.6 & 5.7 & 5.7 & 6.3 \\
\hline Crude protein ${ }^{2}$ & 16.7 & 16.7 & 16.5 & 16.7 \\
\hline Ether extract ${ }^{2}$ & 2.8 & 2.3 & 2.0 & 2.2 \\
\hline $\mathrm{NDF}^{2}$ & 59.1 & 59.5 & 57.1 & 57.9 \\
\hline $\mathrm{ADF}^{2}$ & 31.4 & 33.1 & 31.8 & 32.4 \\
\hline $\mathrm{NDF}_{\mathrm{ap}}{ }^{2}$ & 43.1 & 43.5 & 41.7 & 40.6 \\
\hline $\mathrm{iNDF}^{2}$ & 15.1 & 17.0 & 16.9 & 18.0 \\
\hline Lignin $^{2}$ & 3.8 & 5.7 & 4.4 & 6.1 \\
\hline NIND $^{3}$ & 12.1 & 12.8 & 12.3 & 12.7 \\
\hline NIAD $^{3}$ & 3.4 & 4.7 & 4.7 & 4.6 \\
\hline Total carbohydrates $^{2}$ & 75.0 & 75.3 & 78.1 & 74.8 \\
\hline Non-fibrous carbohydrates ${ }^{2}$ & 31.8 & 47.9 & 36.3 & 34.1 \\
\hline \multicolumn{5}{|c|}{$\begin{array}{l}{ }^{1} \text { Mineral supplement composition (Amount/ kg of supplement): Calcium - } 155 \mathrm{~g} \text {; Phosphor - } 65 \mathrm{~g} \text {; Sodium - } 155 \mathrm{~g} \text {; Sulfur - } 12 \mathrm{~g} \text {; } \\
\text { Magnesium - } 6 \mathrm{~g} \text {; Copper - } 100 \mathrm{mg} \text {; Cobalt - } 175 \mathrm{mg} \text {; Iron - } 1.000 \mathrm{mg} \text {; Iodine - } 175 \mathrm{mg} \text {; Manganese - } 1.400 \mathrm{mg} \text {; Selenium - 27; m; } \\
\text { Zinc - } 6.000 \mathrm{mg} \text {; Níckel - } 42 \mathrm{mg} \text {; Fluorine - } 650 \mathrm{mg} \text {. NDF: neutral detergent fiber; ADF: acid detergente fiber; NIND: nitrogen } \\
\text { insoluble in neutral detergent; NIAD: nitrogen insoluble in acid detergent; iNDF: indigestible neutral detergent fiber; NDFap: neutral } \\
\text { detergent fiber free from ashes and protein; }{ }^{2} \text { Values in percentage of dry matter. }{ }^{3} \text { Values in percentage of Total Nitrogen }(\% \text { TN). }\end{array}$} \\
\hline
\end{tabular}

Samples of the ingredients, supplied diets, and leftovers (forming a composed mixture by animal) were collected and conditioned in a freezer at $-10^{\circ} \mathrm{C}$. An aliquot was removed from the samples every 15 days for further analysis of the chemical and bromatological composition (Table 1), determination of dry matter consumption (DM), and nutrient consumption (Table 2).

The content of dry matter (DM), organic matter $(\mathrm{OM})$, crude protein $(\mathrm{CP})$, ether extract (EE), and acid detergent fiber (ADF) were determined (AOAC, 2010). For the neutral detergent fiber (NDF) analyses, the samples were treated with thermostable alpha-amylase and corrected for residual ash (Mertens, 2002). The NDF and ADF were corrected for nitrogen compounds and estimation of the contents of insoluble nitrogenous compounds in neutral (NIND) and acid detergent (NIAD) (Licitra et al., 1996). Lignin was obtained as described by Detmann et al. (2012). The total carbohydrate (TC) and non-fibrous carbohydrate (NFC) content were calculated according to Sniffen et al. (1992). The total digestible nutrient content (TDN) was determined according to the system developed by Cornell University (Sniffen et al., 1992).

The sheep were weighed at the beginning and at the end of the adaptation period and every 15 days throughout the confinement to obtain the final body weight $(\mathrm{kg})$. Before the slaughter, a new weighing was performed (after 16h of fasting of solid food and water diet) to evaluate the total 
weight gain (TWG) and daily average (DAG) (Table 2).

The slaughter was carried out under the Regulations of the Industrial and Sanitary Inspection of Products of Animal Origin-

Table 2. Nutrient consumption and performance of Dorper x Santa Inês lambs submitted to diets containing alternative foods.

\begin{tabular}{|c|c|c|c|c|c|}
\hline \multirow{2}{*}{ Variable } & \multicolumn{4}{|c|}{ Dieta } & \multirow[b]{2}{*}{ General mean } \\
\hline & Traditional & Cottonseed & Sunflower meal & $\begin{array}{c}\text { Castor bean } \\
\text { cake }\end{array}$ & \\
\hline $\mathrm{DMC}_{(\mathrm{kg} / \mathrm{day})}$ & 1.08 & 1.07 & 1.10 & 1.26 & 1.12 \\
\hline $\mathrm{DMC}_{(\% \mathrm{BW})}$ & 3.93 & 3.65 & 3.90 & 4.50 & 4.00 \\
\hline $\left.\operatorname{DMC}_{(\mathrm{g} / \mathrm{kg}} \mathrm{g}^{0,75}\right)$ & 89.61 & 84.74 & 89.50 & 102.47 & 91.58 \\
\hline $\mathrm{CPC}_{(\mathrm{kg} / \mathrm{day})}$ & 0.28 & 0.27 & 0.23 & 0.29 & 0.27 \\
\hline $\mathrm{EEC}_{(\mathrm{kg} / \mathrm{day})}$ & 0.03 & 0.02 & 0.02 & 0.03 & 0.03 \\
\hline $\mathrm{NDFC}_{(\mathrm{kg} / \mathrm{day})}$ & 0.60 & 0.60 & 0.58 & 0.68 & 0.61 \\
\hline $\mathrm{ADFC}_{(\mathrm{kg} / \mathrm{day})}$ & 0.30 & 0.32 & 0.31 & 0.37 & 0.33 \\
\hline $\operatorname{NDFapC}_{(\mathrm{kg} / \text { day })}$ & 0.42 & 0.42 & 0.42 & 0.46 & 0.43 \\
\hline $\mathrm{CCNF}_{(\mathrm{kg} / \mathrm{dia})}$ & 0.36 & 0.37 & 0.43 & 0.46 & 0.40 \\
\hline $\mathrm{NDT}_{(\mathrm{kg} / \mathrm{dia})}$ & 0.62 & 0.71 & 0.67 & 0.81 & 0.70 \\
\hline $\mathrm{PVI}_{(\mathrm{kg})}$ & 19.60 & 19.60 & 21.92 & 19.20 & 20.08 \\
\hline $\mathrm{FLW}_{(\mathrm{kg})}$ & 34.26 & 35.67 & 35.90 & 38.51 & 36.08 \\
\hline $\mathrm{TWG}_{(\mathrm{kg})}$ & 14.85 & 16.08 & 13.97 & 19.31 & 16.05 \\
\hline $\mathrm{ADG}_{(\mathrm{g})}$ & 161.60 & 174.60 & 151.80 & 209.80 & 174.45 \\
\hline FC & 6.53 & 6.27 & 7.26 & 6.09 & 6.54 \\
\hline
\end{tabular}

DMC - dry matter consumption; CPC - crude protein consumption; EEC - ether extract consumption; NDFC - neutral detergent fiber consumption; NDFapC - neutral detergent fiber free from ashes and protein consumption; ADFC - acid detergent fiber consumption; NFCCapC - non-fibrous carbohydrate corrected for ashes and proteins consumption; TDNT - total digestible nutrients consumption; PVI - initial live weight; FLW - final live weight; TWG - total weight gain; ADG - average daily gain; FC - feed conversion; $\mathrm{N}=20$.

In the left half carcass, the $\mathrm{pH}$ measurements (hydrogenation potential) with the aid of a portable digital peagameter (DM20, Digimed) were performed on the Longissimus lumborum muscle at the $11^{\text {th }}$ and $13^{\text {th }}$ thoracic vertebrae, with an insertion electrode and a resolution of 0.01 units of $\mathrm{pH}$, which was previously calibrated with standard solutions of $\mathrm{pH} 4.0$ and 7.0. For the verification of the $\mathrm{pH}$ measurements, a small muscle incision was made to facilitate the introduction of the glass electrode. The $\mathrm{pH}$ value was taken for about 30 seconds until the value was stabilized, with three readings per carcass at the following times: $0,1,2,3,4,6$, $8,10,13,16,20$, and 24 hours post-mortem. At the same time intervals, the carcass temperature (internal and external) and the temperature and air relative humidity of the cold chamber were measured. The internal temperature of the carcass was checked using a digital insertion thermometer and a surface thermometer was used to measure the carcass external temperature. The temperature and air relative humidity of the cold chamber were measured using a digital thermo-hygrometer. The
RIISPOA (BRASIL, 2017) at the UECO-Goats and Sheep Experiment Unit/UESB, through stunning by cerebral concussion, jugular vein cut, and carotid artery cut. The carcasses were kept in a cold chamber $\left(4^{\circ} \mathrm{C}\right)$ for 24 hours. 
The lambs submitted to the diet with the castor bean cake presented lower $\mathrm{pH}$ of carcass (5.78), in the period of $24 \mathrm{~h}$. The initial glycogen concentration depends on the conditions that the animals are exposed to during the pre-slaughter periods and according to Apaoblaza et al. (2020) the type of feed can affect total energy intake, deposition of glycogen, and antioxidants. Therefore, the diet, its composition in lipids, carbohydrates, proteins, or micronutrients can alter the metabolism of muscle energy. Through biochemical reactions that take place in the mitochondria, most of the nutrients are transformed into energy, where molecules of carbohydrates, proteins, and fats are metabolized, which is associated with the production of a molecule with chemical bonds rich in energy used by all cells as a kind of energy currency, adenosine triphosphate (ATP) (Kowaltowski, 2015).

The oxygen supply ceases after slaughter and the remaining oxygen is rapidly consumed, resulting in extreme hypoxia conditions. The lack of oxygen activates the anaerobic pathways. Glycogen is then metabolized by anaerobic pathways to generate the necessary ATP, producing lactate, and $\mathrm{H}^{+}$, accelerating the $\mathrm{pH}$ drop in the muscle as lactate accumulates (Álvarez et al., 2019), thus gradually reducing the $\mathrm{pH}$ as the post-mortem period progresses, as observed throughout the evaluation hours (Table $3)$.

Table 3. $\mathrm{pH}$ of carcass of Dorper $\mathrm{x}$ Santa Inês lambs submitted to diets containing alternative foods.

\begin{tabular}{|c|c|c|c|c|c|c|c|c|c|}
\hline \multirow{2}{*}{$\begin{array}{c}\text { Hour } \\
\text { post- } \\
\text { mortem }\end{array}$} & \multicolumn{4}{|c|}{ Diet } & \multirow{2}{*}{$\begin{array}{c}\text { General } \\
\text { mean }\end{array}$} & \multirow[b]{2}{*}{ SEM } & \multicolumn{3}{|c|}{$\operatorname{Pr}>\mathrm{F}$} \\
\hline & Traditional & Cottonseed & $\begin{array}{c}\text { Sunflower } \\
\text { meal }\end{array}$ & $\begin{array}{c}\text { Castor } \\
\text { bean cake }\end{array}$ & & & Diet & Hour & $\begin{array}{l}\text { Diet } x \\
\text { Hour }\end{array}$ \\
\hline \multicolumn{10}{|c|}{$p H$} \\
\hline 1 & 6.87 & 6.84 & 7.24 & 6.59 & $6.88 \mathrm{~A}$ & 0.1216 & & & \\
\hline 2 & 6.04 & 5.83 & 6.11 & 6.04 & $6.01 \mathrm{~B}$ & 0.0629 & & & \\
\hline 3 & 5.89 & 5.69 & 5.94 & 5.82 & 5.83BCDE & 0.0497 & & & \\
\hline 4 & 6.06 & 5.68 & 5.95 & 5.63 & 5.83BCDE & 0.0703 & & & \\
\hline 5 & 6.04 & 5.96 & 6.21 & 5.52 & 5.93BCD & 0.1040 & & & \\
\hline 6 & 5.97 & 5.94 & 6.01 & 5.97 & $5.97 \mathrm{BC}$ & 0.0531 & $<0.0001$ & $<0.0001$ & 0.4521 \\
\hline 7 & 5.86 & 5.71 & 5.98 & 5.85 & 5.85BCDE & 0.0551 & & & \\
\hline 8 & 5.64 & 5.58 & 5.81 & 5.68 & $5.67 \mathrm{DE}$ & 0.0401 & & & \\
\hline 9 & 5.65 & 5.65 & 5.76 & 5.58 & $5.66 \mathrm{E}$ & 0.0362 & & & \\
\hline 10 & 5.66 & 5.68 & 5.79 & 5.56 & $5.67 \mathrm{DE}$ & 0.0419 & & & \\
\hline 11 & 5.65 & 5.70 & 5.81 & 5.61 & $5.69 \mathrm{DE}$ & 0.0372 & & & \\
\hline 12 & 5.69 & 5.72 & 5.79 & 5.61 & 5.71CDE & 0.0390 & & & \\
\hline $\begin{array}{l}\text { General } \\
\text { mean }\end{array}$ & $5.92 \mathrm{ab}$ & $5.83 \mathrm{bc}$ & $6.03 \mathrm{a}$ & $5.78 \mathrm{c}$ & & 0.0276 & & & \\
\hline
\end{tabular}

Means followed by distinct letters differed from each other $(\mathrm{P}<0.05)$ by the Tukey test. In the lines, lowercase letters and, in the columns, capital letters; SEM - standard error of the mean. Pr > F - probability obtained from the split-plot in time study. $\mathrm{N}=20$.

The initial $\mathrm{pH}$ (hour 0) of the carcass was 6.88; reached a value of 6.01 after the period of 1 hour and 5.71 at the end of the 24 hours postslaughter. In live animals, the $\mathrm{pH}$ is at physiological levels; usually, values are close to neutrality, decreasing with time after slaughter. Physiologically, muscle $\mathrm{pH}$ decreases from 7.0 shortly after slaughter to approximately 5.4 to 5.8 , so that the $\mathrm{pH}$ reduction during cooling occurs mainly between 6 and 12 hours (Savell et al., 2005; Adeyemi and Sazili, 2014).

The consumption of different diets by the lambs allowed adequate muscle $\mathrm{pH}$ at the beginning of rigor mortis (onset rigor), with no effect of diets on this characteristic $(\mathrm{p}=0.7730)$ with a mean value of 6.02 . According to Álvarez et al. (2019), this initial phase of rigor mortis usually occurs when the muscle $\mathrm{pH}$ drops to 5.9. The rigor mortis started when carcasses temperature reached $22.55^{\circ} \mathrm{C}$ (mean value), also without diet interference $(\mathrm{p}=0.3864)$ (Table 4). The temperature at which the rigor begins is favorable to gains in lamb meat tenderness because according to Hertzman et al. (1993) this characteristic is negatively affected when the muscle initiates the rigor in temperature above $25^{\circ} \mathrm{C}$, thus disfavoring the intense activity of calpain (Adeyemi and Sazili, 2014).

The onset $\mathrm{pH}$ in Longissimus lumborum occurred after $6.2 \mathrm{~h}$ (traditional diet); $4.4 \mathrm{~h}$ (cottonseed diet); $4.0 \mathrm{~h}$ (sunflower meal diet); and $3.8 \mathrm{~h}$ (castor bean cake diet) after the slaughter. 
The intense decline in $\mathrm{pH}$ combined with the abnormal pre-rigor cooling temperature can affect glycolysis, muscle proteins in the post-mortem, and thus the qualitative attributes of the meat produced (Kim et al., 2014). In this evaluation, the beginning of the process was adequate, and the $\mathrm{pH}$ decline suggests characteristics of a normal curve, indicative of good quality meat.

The internal temperature of the carcass was influenced by the diets $(\mathrm{p}<0.0001)$ and hours of evaluation $(\mathrm{p}<0.0001)$ (Table 4$)$. The animals that received the alternative feed containing diets presented higher internal carcass temperature than those that consumed the traditional diet, which favored the greater reduction in the internal temperature $\left(19.22^{\circ} \mathrm{C}\right)$, which may be related to the resulting body condition, especially the amount of fat deposited in the carcass. Subcutaneous fat acts as a thermal insulator, slowing down the carcass's cooling speed, preventing dehydration, browning, and diminishing meat tenderness. Carcasses that are cooled very quickly, before entering rigor mortis, may present increased meat hardness because the sarcomeres of the muscular tissue reach a very small size (Santos et al., 2018).

Table 4. Internal temperature of Dorper $x$ Santa Inês lambs submitted to diets containing alternative foods.

\begin{tabular}{|c|c|c|c|c|c|c|c|c|c|}
\hline \multirow[b]{2}{*}{ Hour } & \multicolumn{4}{|c|}{ Diet } & \multirow[b]{2}{*}{$\begin{array}{c}\text { General } \\
\text { mean }\end{array}$} & \multirow[b]{2}{*}{ SEM } & \multicolumn{3}{|c|}{$\operatorname{Pr}>\mathbf{F}$} \\
\hline & Traditional & Cottonseed & $\begin{array}{c}\text { Sunflower } \\
\text { meal }\end{array}$ & $\begin{array}{c}\text { Castor } \\
\text { bean cake }\end{array}$ & & & Diet & Hour & $\begin{array}{l}\text { Diet } x \\
\text { Hour }\end{array}$ \\
\hline \multicolumn{10}{|c|}{ Temperatura interna da carcaça } \\
\hline 1 & 38.20 & 38.53 & 38.27 & 37.53 & $38.13 \mathrm{~A}$ & 0.2349 & & & \\
\hline 2 & 30.33 & 32.07 & 31.20 & 31.07 & 31.16B & 0.3219 & & & \\
\hline 3 & 26.13 & 27.80 & 27.33 & 26.87 & $27.03 \mathrm{C}$ & 0.3019 & & & \\
\hline 4 & 23.47 & 24.47 & 24.33 & 23.80 & $24.02 \mathrm{D}$ & 0.2730 & & & \\
\hline 5 & 21.53 & 22.80 & 22.93 & 21.93 & $22.30 \mathrm{E}$ & 0.2798 & & & \\
\hline 6 & 19.46 & 20.34 & 20.47 & 20.00 & $20.06 \mathrm{~F}$ & 0.3178 & $<0.0001$ & $<0.0001$ & 0.1841 \\
\hline 7 & 17.20 & 17.60 & 17.67 & 18.00 & $17.62 \mathrm{G}$ & 0.2285 & & & \\
\hline 8 & 15.20 & 15.80 & 15.40 & 16.27 & $15.66 \mathrm{H}$ & 0.2952 & & & \\
\hline 9 & 12.73 & 13.13 & 12.80 & 14.20 & $13.22 \mathrm{I}$ & 0.2976 & & & \\
\hline 10 & 10.60 & 11.07 & 10.40 & 11.60 & $10.92 \mathrm{~J}$ & 0.2626 & & & \\
\hline 11 & 8.27 & 8.87 & 8.47 & 9.20 & $8.70 \mathrm{~K}$ & 0.1963 & & & \\
\hline 12 & 7.47 & 7.27 & 7.27 & 7.93 & $7.48 \mathrm{~L}$ & 0.1460 & & & \\
\hline $\begin{array}{c}\text { General } \\
\text { mean }\end{array}$ & $19.22 \mathrm{~b}$ & $19.98 \mathrm{a}$ & $19.71 \mathrm{a}$ & $19.87 \mathrm{a}$ & & 0.5836 & & & \\
\hline
\end{tabular}

Means followed by distinct letters differed from each other $(\mathrm{P}<0.05)$ by the Tukey test. In the lines, lowercase letters and, in the columns, capital letters; SEM - standard error of the mean. Pr $>$ F - probability obtained from the split-plot in time study. $\mathrm{N}=20$.

As the post-slaughter time advances, the internal carcass temperature reduces, which shows the development of rigor mortis and refrigeration efficiency. The gradual decrease in muscle temperature contributes to the adequate performance of proteases, furthermore, according to Hwang et al. (2004), without damage due to protein denaturation, such as the marked drop in $\mathrm{pH}$ at the beginning of the post-mortem or the delay of the rigor mortis process, which did not occur. When subjected to refrigeration, the carcasses reached a temperature suitable for the satisfactory occurrence of $\mathrm{pH}$ drop as previously verified (final $\mathrm{pH}$ between 5.61 and 5.79).

The final temperature (24 hours) was $7.48^{\circ} \mathrm{C}$ (average value), agreeing with the recommended value $\left(7^{\circ} \mathrm{C}\right)$, at the moment of meat delivery by slaughter establishments for commercialization (MARA, 1996). In addition, the right temperature protects the carcass from quality damage, as to avoid shortening by cold, lamb carcasses should not be refrigerated at values lower than $3^{\circ}$ and $4^{\circ} \mathrm{C}$ in the period from 12 to 14 hours post-slaughter (Sheridan, 1990).

In general, the muscle $\mathrm{pH}$ correlated moderately and positively with the temperature of the carcass (internal and external) and cold chamber, in the different diets evaluated (Table 5). Therefore, the higher the temperature of the internal carcass, external surface, and cold chamber, the higher the $\mathrm{pH}$ decline, and, consequently, the faster the rigor mortis process in the muscle occurs, emphasizing the interaction between $\mathrm{pH}$ and temperature (both of carcass and environment) during animal post-mortem. The abnormal occurrence of high pre-rigor temperature accompanied by a faster than normal $\mathrm{pH}$ decline in muscle has been shown to have negative impacts on meat quality attributes. The accelerated rates of muscle glycolysis early in the 
post-mortem result in low $\mathrm{pH}$ of the muscle when the muscle temperature is still high (and generally above average), causing denaturation of muscle proteins (Kim et al., 2014). The gradual decrease in muscle temperature, on the other hand, provides the proper performance of proteolytic enzymes without the inconveniences resulting from protein denaturation (sharp drop in $\mathrm{pH}$ at the beginning of post-mortem) or the delay in the rigor mortis process such as shortening by cold (Hwang et al., 2004).
The relative humidity of the cold chamber correlated with the muscle $\mathrm{pH}$ of the lamb carcass that received the traditional diet and the one containing sunflower meal, although this relationship is not very significant as there is a low correlation value. The supply of both diets to the lambs allowed the existence of a positive correlation with values ranging from moderate to high between the relative humidity of the cold chamber and the temperature (internal and external of the carcass; and the cold chamber) (Table
$5)$.

Table 5. Correlation between the measurements of muscle $\mathrm{pH}$, internal and external temperature of the carcass, in post-mortem Dorper x Santa Inês lambs submitted to diets with alternative foods, and temperature and humidity of the cold chamber.

\begin{tabular}{|c|c|c|c|c|}
\hline \multirow[b]{2}{*}{ Diet } & \multicolumn{4}{|c|}{ Measures } \\
\hline & ITC & ETC & CCT & RHCC \\
\hline $\begin{array}{c}\text { Traditional } \\
\text { pH } \\
\text { ITC } \\
\text { ETC } \\
\text { CCT } \\
\end{array}$ & $0.69^{(* *)}$ & $\begin{array}{l}0.72^{(* *)} \\
0.97^{(* *)}\end{array}$ & $\begin{array}{l}0.52^{(* *)} \\
0.84^{(* *)} \\
0.84^{(* *)}\end{array}$ & $\begin{array}{l}0.37^{(*)} \\
0.65^{(* *)} \\
0.64^{(* *)} \\
0.88^{(* *)}\end{array}$ \\
\hline $\begin{array}{c}\text { Cottonseed } \\
\text { pH } \\
\text { ITC } \\
\text { ETC } \\
\text { CCT }\end{array}$ & $0.56^{(* *)}$ & $\begin{array}{l}0.63^{(* *)} \\
0.97^{(* *)}\end{array}$ & $\begin{array}{c}0.31^{(*)} \\
0.87^{(* *)} \\
0.86^{(* *)}\end{array}$ & $\begin{array}{c}- \\
0.72^{(* *)} \\
0.70^{(* *)} \\
0.91^{(* *)}\end{array}$ \\
\hline $\begin{array}{c}\text { Sunflower meal } \\
\text { pH } \\
\text { ITC } \\
\text { ETC } \\
\text { CCT } \\
\end{array}$ & $0.61^{(* *)}$ & $\begin{array}{l}0.64^{(* *)} \\
0.97^{(* *)}\end{array}$ & $\begin{array}{l}0.41^{(* *)} \\
0.89^{(* *)} \\
0.87^{(* *)}\end{array}$ & $\begin{array}{l}0.26^{(*)} \\
0.71^{(* *)} \\
0.67^{(* *)} \\
0.88^{(* *)}\end{array}$ \\
\hline $\begin{array}{c}\text { Castor bean cake } \\
\text { pH } \\
\text { ITC } \\
\text { ETC } \\
\text { CCT }\end{array}$ & $0.65^{(* *)}$ & $\begin{array}{l}0.66^{(* *)} \\
0.97^{(* *)}\end{array}$ & $\begin{array}{c}0.29^{(*)} \\
0.77^{(* *)} \\
0.78^{(* *)}\end{array}$ & $\begin{array}{c}- \\
0.51^{(* *)} \\
0.53^{(* *)} \\
0.89^{(* *)}\end{array}$ \\
\hline
\end{tabular}

ITC - internal temperature of the carcass; ETC - external temperature of the carcass; CCT - cold chamber temperature; RHCC relative humidity of the cold chamber; $(* *)$ Effect of significant correlation at $1 \%$ and $(*)$ at $5 \%$ probability, respectively.

Humidity and temperature influence the heat loss, in this case, from the carcass to the environment. As the temperature of the cold chamber decreases, through heat transfer to the environment, cooling of the muscle and of the carcass external temperature will occur. Considering that the relative humidity is defined as the relation between the air vapor pressure and the possible saturation vapor pressure, under the same temperature, the capacity of humidity retention by the air increases with the temperature rise and occurs until the stored product reaches equilibrium, i.e. the number of water molecules that enter and leave the vapor phase is the same (Chitarra and Chitarra, 2005).
The existence of these correlations also highlights the need to monitor temperature and humidity; and their adjustment at the moment before receiving the carcasses, because they act on important processes during the transformation of the muscle into meat (rigor mortis), being determinant on meat qualitative aspects. According to Kuffi et al. (2018), the combination of cooling rate and $\mathrm{pH}$ decline determines the fate of the final meat quality such as tenderness which then indicates the importance of knowing the conversion rates of energy substrates that are linked to changes in $\mathrm{pH}$ and the temperature of the muscles to obtain a wholesome meat product. 


\section{Conclusion}

The use of formulated diets with alternative foods for lambs promotes adequate development of the rigor mortis process, in terms of $\mathrm{pH}$ and carcass temperature decrease, typical to the production of good quality meat.

\section{Conflict of Interest}

The authors declare no conflict of interest.

\section{Ethics Committee}

The research project was approved by the Animal Use Ethics Committee of the Universidade Estadual do Sudoeste da Bahia, under the number 24/2013.

\section{References}

Adeyemi, K.D.; Sazili, A.Q. Efficacy of carcass electrical stimulation in meat quality enhancement: a review. Asian-Australasian Journal Animal Science, 27(3): 447-456, 2014.

Apaoblaza, A.; Gerrard, S.; Matarneh, S.K.; Wicks, J.; Kirkpatrick, L; England, E.; Scheffler, T.L.; Duckett, S.K.; Shi, H.; Silva, S.L.; Grant, A.L.; Gerrard, D.E. Muscle from grass- and grain-fed beef differs energetically. Meat Science, 161(1): 107996, 2020.

AOAC. Association of Official Analytical Chemists. Official Methods of Analysis. $18^{\text {th }}$ ed. Washington: AOAC, 2010. 1094p.

Álvarez, C.; Morán, L.; Keenan, D.F.; Mullen, A. Delgado-Pando, G. Mechanical and biochemical methods for rigor measurement: relationship with eating quality. Journal of Food Quality, 2019: 1-13, 2019.

Bate-Smith, E.C.; Bendall, J.R. Factors determining the time course of rigor mortis. The Journal of Physiology, 110(1-2): 47-65, 1949.

BRASIL. Ministério da Agricultura, Pecuária e Abastecimento. Decreto $\mathbf{N}^{\mathbf{0}} \mathbf{9 . 0 1 3}$, de 29 março de 2017. Disponível em: <http://www.planalto.gov.br/ccivil_03/_Ato20 15-2018/2017/Decreto/D9013.htm\#art541.> Acesso em: 11 jun. 2018.

Chitarra, M.I.F.; Chitarra, A.B. Pós-colheita de frutos e hortaliças: fissiologia e manuseio. $2^{\mathrm{a}}$ ed. Lavras: Universidade Federal de Lavras, 2005. 783p.

Detmann, E.; Souza, M.A.; Valadares Filho, S.C.; Queiroz, A.C.; Berchielli, T.T.; Saliba, E.O.S.; Cabral, L.S.; Pina, D.S.; Ladeira, M.M.;
Azevedo, J.A.G. Métodos para análise de alimentos - INCT - Ciência Animal. Visconde do Rio Branco: Suprema, 2012. $214 p$.

Ferguson, D.M.; Gerrard, D.E. Regulation of postmortem glycolysis in ruminant muscle. Animal Production Science, 54(4): 464-481, 2014.

Hertzman, C.; Olsson, U.; Tornberg, E. The influence of high temperature, type of muscle and electrical stimulation on the course of rigor, ageing and tenderness of beef muscles. Meat Science, 35(1): 119-141, 1993.

Hwang, I.H.; Park, B.Y.; Cho, S.H.; Lee, J.M. Effects of muscle shortening and proteolysis on Warner-Bratzler shear force in beef longissimus and semitendinosus. Meat Science, 68(3): 497-505, 2004.

Kim, Y.H.B.; Warner, R.D.; Rosenvold, K. Influence of high pre-rigor temperature and fast $\mathrm{pH}$ fall on muscle proteins and meat quality: a review. Animal Production Science, 54(4): 375-395, 2014.

Kowaltowski, A. O que é metabolismo? como nossos corpos transformam o que comemos, no que somos. São Paulo: Oficina de Textos, 2015. 112p.

Kuffi, K.D.; Lescouhier, S.; Nicolai, B.M.; De Smet, S.; Geeraerd, A.; Verboven, P. Modelling postmortem evolution of $\mathrm{pH}$ in beef M. biceps femoris under two different cooling regimes. Journal of Food Science and Technology, 55(1): 233-243, 2018.

Licitra, G.; Hernandez, T.M.; Van Soest, P.J. Standardization of procedures for nitrogen fractionation of ruminant feeds. Animal Feed Science and Technology, 57(4): 347-358, 1996.

MARA. Ministério Estadual da Agricultura e da Reforma Agrária. Portaria $\mathrm{N}^{\circ}$ 304, de 22 de abril de 1996. Disponível em: $<$ https://www.defesa.agricultura.sp.gov.br/legi slacoes/portaria-mara-304-de-22-041996,691.html.> Acesso em: 11 jun. 2018.

Mertens, D.R. Gravimetric determination of amylase-treated neutral detergent fiber in feeds with refluxing beakers or crucibles: collaborative study. Journal of AOAC International, 85: 1217-1240, 2002.

NRC. National Research Council. Nutrient requeriments of small ruminants. $1^{\text {st }}$ ed. Washington, DC, USA: National Academy Press, 2007. 362p. 
Oliveira, M.D.S.; Mota, D.A.; Barbosa, J.C.; Stein, M.; Borgonovi, F. Composição bromatológica e digestibilidade ruminal in vitro de concentrados contendo diferentes níveis de torta de girassol. Ciência Animal Brasileira, 8(4): 629-638, 2007.

Santos, A.C.P.; Silva, B.C.D.; Oliveira, V.S.; Valença, R.L. Métodos de avaliação de carcaça e de carne dos animais através de predições in vivo e post mortem - revisão de literatura. Revista Científica de Medicina Veterinária, 30: 1-21, 2018.

Santos, G.C.L.; Gonzaga Neto, S.; Bezerra, L.R.; Medeiros, A.N. Uso de tortas na alimentação de vacas leiteiras: uma revisão. Brazilian Journal of Animal and Environmental Research, 3 (1): 89-113, 2020.
SAS®. Statistical Analytical System. System for Mixed Models. Users guide: statistics. Cary: SAS Inst. Inc., 2001.

Savell, J.W.; Mueller, S.L.; Baird, B.E. The chilling of carcasses. Meat Science, 70: 449459, 2005.

Scarpino, F.B.O.; Ezequiel, J.M.B.; Silva, D.A.V.; Van Cleef, E.H.C.B. Óleo de soja e óleo de soja residual em dietas para ovinos confinados: parâmetros sanguíneos. Archivos de Zootecnia, 63(241): 207-210, 2014.

Sheridan, J.J. The ultra-rapid chilling of lamb carcasses. Meat Science, 28: 31-50, 1990.

Sniffen, C.J.; O’Connor, J.D.; Van Soest, P.J.; Fox, D.G.; Russell, J.B. A net carbohydrate and protein system for evaluating cattle diets: II. Carbohydrate and protein availability. Journal Animal Science, 70(11): 3562-3577, 1992. 